\title{
OPEN
}

\section{Publisher Correction: Uncovering Sub-Structure and Genomic Profiles in Across-Countries Subpopulations of Angus Cattle}

Diercles Francisco Cardoso, Gerardo Alves Fernandes Júnior, Daiane Cristina Becker Scalez, Anderson Antonio Carvalho Alves, Ana Fabrícia Braga Magalhães, Tiago Bresolin, Ricardo Vieira Ventura, Changxi Li, Márcia Cristina de Sena Oliveira, Laercio Ribeiro Porto-Neto, Roberto Carvalheiro, Henrique Nunes de Oliveira, Humberto Tonhati \& Lucia Galvão Albuquerque

Correction to: Scientific Reports https://doi.org/10.1038/s41598-020-65565-1, published online 29 May 2020

In the original version of this Article, Gerardo Alves Fernandes Júnior was incorrectly affiliated with 'Present address: Centre for Genetic Improvement of Livestock, Department of Animal Biosciences, University of Guelph, Guelph, ON, Canada.'

In addition, an affiliation was omitted for Daiane Cristina Becker Scalez. The correct affiliations are listed below.

Gerardo Alves Fernandes Júnior:

Department of Animal Science, School of Agricultural and Veterinarian Science, São Paulo State University (UNESP), Jaboticabal, SP, Brazil.

Daiane Cristina Becker Scalez:

Department of Animal Science, School of Agricultural and Veterinarian Science, São Paulo State University (UNESP), Jaboticabal, SP, Brazil.

Present address: Centre for Genetic Improvement of Livestock, Department of Animal Biosciences, University of Guelph, Guelph, ON, Canada.

These errors have been corrected in the PDF and HTML versions of the Article.

\begin{abstract}
(c) (1) Open Access This article is licensed under a Creative Commons Attribution 4.0 International (c) License, which permits use, sharing, adaptation, distribution and reproduction in any medium or format, as long as you give appropriate credit to the original author(s) and the source, provide a link to the Creative Commons license, and indicate if changes were made. The images or other third party material in this article are included in the article's Creative Commons license, unless indicated otherwise in a credit line to the material. If material is not included in the article's Creative Commons license and your intended use is not permitted by statutory regulation or exceeds the permitted use, you will need to obtain permission directly from the copyright holder. To view a copy of this license, visit http://creativecommons.org/licenses/by/4.0/.
\end{abstract}

(C) The Author(s) 2020 